\title{
A study of the renal profile in ART naive HIV/AIDS patients
}

\author{
Baruah $R^{1}$, Baishya $H^{2}$, Baruah $S^{3}$ \\ Received on April 29, 2019; editorial approval on May 26, 2019
}

\begin{abstract}
Background: As HIV/AIDS has emerged to be the first modern pandemic with ever increasing prevalence globally, the present study was undertaken to study the renal profile in patients living with HIV/AIDS, not started on ART. Materials and methods: This was a hospital based observational study where 277 cases were studied in details with the aims and objectives of studying the renal manifestations in ART naïve patients with HIV/AIDS and its relationship with CD4 counts. $A$ detailed history, clinical examination and relevant investigations were done in patients above 15 yrs of age who were not on ART. Results: Out of 277 seropositives, 40 had proteinuria (14.44\%) on urine examination. The mean serum creatinine of the total study population was found to be $0.92 \pm 0.83 \mathrm{mg} / \mathrm{dl}$ while 14 cases $(5 \%)$ had serum creatinine more than $1.5 \mathrm{mg} / \mathrm{dl}$. A decrease in eGFR $\left(<60 \mathrm{ml} / \mathrm{min} / 1.73 \mathrm{~m}^{2}\right)$ was seen in 28 (10.1\%) cases. Out of 178 cases with CD4 count more than 200cells $/ \mathrm{mm}^{3}$, renal dysfunction was found in 12 cases (6.7\%), whereas the cases with CD4 count less than or equal to 200cells $/ \mathrm{mm}^{3}$, 19 out of 99 cases (19.2\%) had renal dysfunction which is statistically significant . Conclusion: In the present study, which included ART naive patients with HIVIAIDS, predominant renal involvement was in the form of proteinuria followed by raised serum creatinine levels and reduced eGFR. A negative correlation was found between renal dysfunction and CD4 counts.
\end{abstract}

Keywords: HIVAN (Human immunodeficiency virus associated nephropathy); Renal dysfunction in HIV; CD4 count.

\section{INTRODUCTION}

As the fourth leading cause of death around the world and the first leading cause of death in Africa, HIV/AIDS continues to affect 36.7 million people worldwide. ${ }^{1}$ The national adult HIV prevalence in India is $0.26 \%$. The total number of People Living with HIV (PLHIV) in India is estimated at 21.17 lakhs of which children account for $6.54 \%$ in $2015 .^{2}$

The clinical consequences of HIV infection encompass a spectrum ranging from an acute clinical syndrome associated with primary infection to a prolonged asymptomatic stage to advanced disease. The spectrum of illnesses changes as the CD4+ T cell count declines.

Diseases of the kidney or genitourinary tract may be a direct consequence of HIV infection, due to an opportunistic infection or neoplasm, or related to drug toxicity. In the preART era, HIV associated nephropathy (HIVAN) was characterised by rapid progression to end-stage renal disease(ESRD) leading to the need for dialysis. With the advent of ART, the natural course of disease has changed increasing the importance of prompt diagnosis and treatment. Despite improved outcomes among persons living with HIV who are treated with antiretroviral therapy, they remain at increased risk for acute and chronic kidney diseases and are important contributors to morbidity and mortality in PLHIV.

Patients with HIVAN typically present with heavy proteinuria and rapidly progressive kidney failure and definitive diagnosis requires kidney biopsy, which reveals focal glomerulosclerosis and tubular microcyst formation with tubulointerstitial inflammation and fibrosis. ${ }^{3}$ HIV type $1(\mathrm{HIV}-1)$ infected
Address for correspondence:
${ }^{1}$ Associate Professor
Mobile: +919435015669
Email: baruah_rumi@yahoo.co.in
Department of Anaesthesiology
Fakaruddin Ali Ahmed Medical College and Hospital, Barpeta
${ }^{2}$ Registrar (Corresponding author)
Mobile: +919435252153
Email: hitakalpa12@gmail.com
${ }^{3}$ Professor and Head
Department of Medicine, Gauhati Medical College and Hospital, Guwahati, Assam and India 
patients are at a greater risk of developing acute and chronic renal diseases. HIV-1 associated nephropathy is now the $3^{\text {rd }}$ leading cause of end stage renal disease in 20-64 years of age in the United States. These patients typically have proteinuria followed by a reduction in the glomerular filtration rate (GFR) that progresses to end stage renal disease in few weeks or months. Overall microalbuminuria is seen in $\sim 20 \%$ of untreated HIV infected patients, significant proteinuria is seen in closer to $2 \%$. The presence of microalbuminuria has been associated with an increase in all-cause mortality rate. ${ }^{4}$ Absolute CD4 counts are accepted as the best indicator of immunologic competence of patients with HIV infection and they are an indirect reflection of HIV viral load and activity. The CD4+ T cell count in patients with HIVAN is usually $<200$ cells $/ \mathrm{mm}^{3}$, but has been reported in patients with higher counts. Lower CD4 counts is also associated with increased risk of AKI in HIV infected patients. ${ }^{5}$

This paper has aimed to study the incidence of renal dysfunction in ART naïve HIV/AIDS patients, different types of renal dysfunction and to find the correlation between renal dysfunction and CD4 count.

\section{MATERIALSAND METHODS}

Study location: This study was conducted at tertiary care hospital. 277 cases were collected from the ART Plus Centre, Department of Medicine and Nephrology departments (both outpatient and inpatient).

Study design: This was a hospital based observational study conducted between $1^{\text {st }}$ July 2016 to $30^{\text {th }}$ June 2017. Approval was taken from the institutional ethics committee. Informed written consent was taken from all the patients included in the study.

Inclusion criteria: (i) HIV positive adult patients (as per NACO guidelines) above 15 years; (ii) Patients not on ART.

Exclusion criteria: (i) All HIV positive children below 15 years (as per NACO guidelines); (ii) Patients with pre-existing renal parenchymal disease due to diabetes, long-standing hypertension, cardiac failure and collagen vascular disease; (iii) Patients who are on antiretroviral therapy.

Patients with serum creatinine $\geq 1.5 \mathrm{mg} / \mathrm{dl}$ were labelled as having renal dysfunction. Patients with renal dysfunction and/ or spot proteinuria $>1+$ or $24-\mathrm{h}$ urinary protein $\geq 500 \mathrm{mg}$ were classified as having renal involvement. ${ }^{6}$ The Cockcroft and Gault equation which estimates creatinine clearance on the basis of serum creatinine level, age, sex and weight was used. The formula is as follows:

$$
\mathrm{eCrCl}=\frac{140-\text { age }(\mathrm{yrs}) \times \text { weight }(\mathrm{kg})}{72 \times \text { s. creat }(\mathrm{mg} / \mathrm{dl})} \quad(\times 0.85 \text { for females })
$$

\section{RESULTS}

\section{Incidence of Proteinuria}

Out of 277 seropositives, 40 had proteinuria (14.44\%) on urine examination. Of these, 36 had $\geq 1+$ spot proteinuria, 2 each had $\geq 2+$ and $\geq 3+$ proteinuria (Table 1). The mean 24 hour urinary protein estimation done in these cases $(n=40)$ was found to be $856.02 \pm 372.88 \mathrm{mg} /$ day. Proteinuria $>1 \mathrm{~g} /$ day was found in 4 cases $(10 \%)$.

Table 1 Incidence of proteinuria

\begin{tabular}{|l|l|l|l|}
\hline $\begin{array}{l}\text { RANGE OF } \\
\text { PROTEINURIA }\end{array}$ & $\begin{array}{l}\text { NUMBER } \\
\text { OF CASES }\end{array}$ & $\begin{array}{l}\text { PERCEN- } \\
\text { TAGE(\%) }\end{array}$ & $\begin{array}{l}\text { Mean 24 } \\
\text { hours Urinary } \\
\text { protein (9mg/d) }\end{array}$ \\
\hline$\leq 1+$ & 36 & 12.99 & $748.13 \pm 98.3$ \\
\hline$\leq 2+$ & 2 & 0.72 & $1374 \pm 246.07$ \\
\hline$\leq 3+$ & 2 & 0.72 & $2280 \pm 113.14$ \\
\hline
\end{tabular}

\section{Analysis of serum creatinine}

The mean serum creatinine of the total study population was found to be $0.92 \pm 0.83 \mathrm{mg} / \mathrm{dl}$. When serum creatinine $\geq 1.5 \mathrm{mg} / \mathrm{dl}$ was considered as renal dysfunction, the mean creatinine levels of that group (14/277) was found to be $3.05 \pm 2.92 \mathrm{mg} / \mathrm{dl}$ $(95 \% \mathrm{CI}=1.37-4.74)$, which is statistically significant $(\mathrm{p}<0.0001)$ (Table 2).

Table 2 Analysis of serum creatinine

\begin{tabular}{|l|l|}
\hline CATEGORY & MEAN CREATININE \\
\hline TOTAL STUDY GROUP & $0.92 \pm 0.83 \mathrm{mg} / \mathrm{dl}$ \\
\hline $\begin{array}{l}\text { CASES WITH RENAL } \\
\text { DYSFUNCTION }\end{array}$ & $3.05 \pm 2.92 \mathrm{mg} / \mathrm{dl}$ \\
\hline
\end{tabular}

\section{Analysis of creatinine clearance}

The total number of cases with decreased creatinine clearance $\left(<60 \mathrm{ml} / \mathrm{min} / 1.73 \mathrm{~m}^{2}\right)$ was seen in $28(10.1 \%)$ cases. CKD stage G3 (moderate to severe renal dysfunction) i.e, creatinine clearance between $30-59 \mathrm{ml} / \mathrm{min} / 1.73 \mathrm{~m}^{2}$ was seen in 23 cases. However, stage $\mathrm{G} 4\left(\mathrm{Cr} \mathrm{cl}=15-29 \mathrm{ml} / \mathrm{min} / 1.73 \mathrm{~m}^{2}\right)$ was seen in 7 cases and $\mathrm{G} 5\left(\mathrm{Cr} \mathrm{cl}<15 \mathrm{ml} / \mathrm{min} / 1.73 \mathrm{~m}^{2}\right)$ was seen in 1 case only (Table 3 ).

Table 3 Analysis of creatinine clearance

\begin{tabular}{|l|l|l|l|}
\hline $\begin{array}{l}\text { CREATININE } \\
\text { CL(ML/MIN) }\end{array}$ & $\begin{array}{l}\text { CKD } \\
\text { STAGE }\end{array}$ & $\begin{array}{l}\text { NUMBER } \\
\text { OF CASES }\end{array}$ & $\begin{array}{l}\text { PERCEN } \\
\text { TAGE(\%) }\end{array}$ \\
\hline$\geq 90$ & G1 & 160 & 57.8 \\
\hline $60-89$ & G & 86 & 31.0 \\
\hline $30-59$ & G & 23 & 8.3 \\
\hline $15-29$ & G4 & 7 & 2.5 \\
\hline$<15$ & G5 & 1 & 0.4 \\
\hline
\end{tabular}

(Range $=5-252.10 \mathrm{ml} / \mathrm{min}$, mean $=103.10 \mathrm{ml} / \mathrm{min}$ )

\section{Renal dysfunction in relation to CD4 counts}

Out of 178 cases with CD4 count more than 200 cells $/ \mathrm{mm}^{3}$, renal dysfunction was found in 12 cases (6.7\%) (Table 4a). Whereas of the 99 cases with CD4 count less than or equal to 200 cells $/ \mathrm{mm}^{3}, 19$ cases $(19.2 \%)$ had renal dysfunction which is statistically significant $(\mathrm{P}$ value $=.01$; relative 
risk $=0.602 ; 95 \% \mathrm{CI}=0.38-0.94)$. The mean $\mathrm{CD} 4$ count in patients with renal involvement was $227.2 \pm 233.63$ cells $/ \mathrm{mm}^{3}$ (Table 4b)while in those without renal involvement was $331.7 \pm 223.4$ cells $/ \mathrm{mm}^{3}$ (P value $<.0001$; relative risk $=2.87$; 95\% CI= 2.07-3.81).

Table 4 Renal dysfunction in relation to CD4 counts

Table 4(a)

\begin{tabular}{|l|l|l|}
\hline CD4 COUNT & $\begin{array}{l}\text { TOTAL NO. } \\
\text { OF CASES }\end{array}$ & $\begin{array}{l}\text { CASES WITH } \\
\text { RENAL } \\
\text { DYSFUNCTION(\%) }\end{array}$ \\
\hline$>200$ cells $/ \mathrm{mm}^{3}$ & 178 & $12(6.7 \%)$ \\
\hline$\leq 200$ cells $/ \mathrm{mm}^{3}$ & 99 & $19(19.2 \%)$ \\
\hline
\end{tabular}

$(\mathrm{P}$ value $=.01)$

Table 4(b)

\begin{tabular}{|l|c|}
\hline CATEGORY & MEAN CD4 COUNT \\
\hline With renal involvement & $227.2 \pm 233.63$ cells $/ \mathrm{mm}^{3}$ \\
\hline Without renal involvement & $331.7 \pm 223.4$ cells $/ \mathrm{mm}^{3}$ \\
\hline
\end{tabular}

\section{DISCUSSION}

$(\mathrm{P}$ value $<.0001)$

In the present study, out of 277 seropositives, 40 had proteinuria (14.44\%) on urine analysis. Of these, $36 \mathrm{had} \geq 1+$ spot proteinuria, 2 each had $\geq 2+$ and $\geq 3+$ proteinuria. This is consistent with the study by Gupta $\bar{V}$ et al $^{6}$ in North India who reported 58 patients out of 392 ART naïve cases to have proteinuria $(14.79 \%)$. Similarly, Varma $\mathrm{P}$. et $\mathrm{al}^{7}$ also reported $25 / 142(17.6 \%)$ HIV positive cases to have proteinuria or abnormal urinary sediment. Janakiraman $\mathrm{H}$ et $\mathrm{al}^{8}$ studied $104 \mathrm{HIV}$ positive patients, albuminuria was observed in $29(27 \%)$ patients. Similarly, Prakash J. et al, ${ }^{9}$ reported proteinuria of $1+$ or more in $112(38.2 \%)$ patients in his study. The discrepancy in the incidence of proteinuria with the present study was probably due to the difference in sample size. The mean 24 hour urinary protein in the cases with spot proteinuria (40/277) was found to be $856.02 \pm 372.88$ $\mathrm{mg} /$ day, in the present study. However, in the study of Gupta $\mathrm{V}$. et $a l^{6}$ the mean 24 hour proteinuria was found to be $1561 \pm 906 \mathrm{mg} /$ day in patients with proteinuria $(n=130)$. The difference with the present study might be due to difference in sample size and inclusion of patients on ART in his study. No patient in the present study had nephrotic range proteinuria. Proteinuria $>1 \mathrm{~g}$ /day was found in 4 cases $(10 \%)$ in the present study which was similar to Prakash J. et al, ${ }^{9}$ who found $16(14.2 \%)$ patients to have proteinuria of more than $1 \mathrm{~g} / 24 \mathrm{~h}$.

The mean serum creatinine of the total study population was found to be $0.92 \pm 0.83 \mathrm{mg} / \mathrm{dl}$. When serum creatinine $>1.5 \mathrm{mg} /$ dl was considered as renal dysfunction, the mean creatinine levels of that group (14/277) was found to be $3.05 \pm 2.92$ $\mathrm{mg} / \mathrm{dl}$, which was higher than the total study population. In a study by Atta MG et al, ${ }^{10}$ the patients with biopsy proven HIV-associated nephropathy and not on ART had a significantly higher mean creatinine level $(7.8 \pm 2.9 \mathrm{mg} / \mathrm{dl})$ at the time of biopsy than those on ART. This was similar to the study by Gupta V et $\mathrm{l}^{6}$ where among a group of 392 ART naïve patients, 74(18.9\%) had renal involvement. Patients with renal dysfunction had a mean serum creatinine of 4.60 $\pm 3.17 \mathrm{mg} \%$ (range 1.7-10.5).

In the present study, the total number of cases with moderate to severe renal dysfunction was found to be $23(8.3 \%)$. However, $\mathrm{Cr} \mathrm{cl}=15-29 \mathrm{ml} / \mathrm{min} / 1.73 \mathrm{~m}^{2}$ was seen $2.5 \%$ and $\mathrm{Cr} \mathrm{cl}<15 \mathrm{ml} / \mathrm{min} / 1.73 \mathrm{~m}^{2}$ was seen in $0.4 \%$. Overall, patients with creatinine clearance $<60 \mathrm{ml} / \mathrm{min}$ were $28(10.1 \%)$. Similarly, the prevalence of CKD in Chinese patients was found to be $5.6 \%$ by Cheung $\mathrm{CY}$ et al. ${ }^{11}$

In the present study, out of 178 cases with CD4 count more than 200 cells $/ \mathrm{mm}^{3}$, renal dysfunction was found in 12 cases . Whereas of the 99 cases with CD4 count less than or equal to 200 cells $/ \mathrm{mm}^{3}, 19$ cases had renal dysfunction. The findings is statistically significant. This findings are similar with studies like Janakiraman H. et al, who studied HIV positive patients, and reported that albuminuria was observed. It revealed a significant negative correlation with CD4 count ${ }^{8}$ HLF Kamga. et al also found that creatinine clearance in HIV positive patients with CD4 count below 200 cells $/ \mathrm{mm}^{3}$ was low while serum creatinine levels were higher though it was not statistically significant. ${ }^{12}$

In the present study, the mean CD4 count in patients with renal involvement was $227.2 \pm 233.63$ cells $/ \mathrm{mm}^{3}$ which was lower than those without renal involvement. The patients with ART naive HIV-associated nephropathy had a lower mean CD4 count $\left(161 \pm 130\right.$ cells $\left./ \mathrm{mm}^{3}\right)$ at the time of biopsy. ${ }^{10}$ In another recent study the mean CD4 count of ART naïve patients was significantly lower in patients with renal involvement as compared to those without renal involvement $\left(180 \pm 154\right.$ vs $302 \pm 201$ cells $\left./ \mathrm{mm}^{3}\right){ }^{6}$

\section{CONCLUSION}

In the present study, which included ART naive patients with HIV/AIDS, predominant renal involvement was in the form of proteinuria followed by raised serum creatinine levels. Creatinine clearance and thus GFR is reduced in HIV/AIDS patients and a negative correlation was found between renal involvement and CD4 counts. Although, proteinuria was present in some HIV/AIDS patients in our study population, this parameter alone is not indicative of HIVAN.

Conflict of Interest: None declared.

Ethical Clearance: Taken.

Source of Funding: None.

\section{REFERENCES}

1. UNAIDS Global AIDS update 2016.

2. National Institute of Medical Statistics and National AIDS Control Organization 2015 Technical Report India: HIV Estimates-2015. New Delhi. 
3. D'Agati V, Suh JI, Carbone L et al. Pathology of HIVassociated nephropathy: a detailed morphologic and comparative study. Kidney Int 1989;35:1358-70.

4. Fauci Anthony S et al, Harrison's principles of internal medicine. 19th ed. 2015 vol 2 p. 1258.

5. Ibrahim F, Naftalin C, Cheserem E et al. Immunodeficiency and renal impairment are risk factors for HIV-associated acute renal failure. AIDS 2010;24(14):2239-44

6. Gupta V, Gupta S, Sinha S, Sharma S K, Dinda A K, Agarwal S K, et al. HIV associated renal disease: A pilot study from north India. Indian J Med Res May 2013;137:950-6.

7. Varma PP, Prasher PK, Deshpande GU, Mani NS, Nema SK, Sayal SK. Spectrum of renal lesions in HIV patients. J Assoc Physicians India 2000;48:1151-4.

8. Janakiraman H, Abraham G, Matthew M, Kuruvilla S, Panikar V, Solomon S, et al. Correlation of CD4 counts with renal disease in HIV positive patients. Saudi J
Kidney Disease Transpl 2008;19:603-7

9. Prakash J, Ganiger V, Prakash S, Sivasankar M, Sunder $\mathrm{S}$, Singh U. Kidney disease in human immunodeficiency virus-seropositive patients: Absence of human immunodeficiency virus-associated nephropathy was a characteristic feature. Indian J Nephrol 2017;27:2716.

10. Atta MG, Gallant JE, Rahman MH, et al. Antiretroviral therapy in the treat-ment of HIV-associated nephropathy. Nephrol Dial Transplant 2006;21:2809-13.

11. Cheung CY, Wong KM, Lee MP, Liu YL, Kwok H, Chung $\mathrm{R}$, et al. Prevalence of chronic kidney disease in Chinese HIV-infected patients. Nephrol Dial Transplant 2007;22:3186-90.

12. Kamga HLF, Assob JCN, Njunda AL, Nde Fon P, Nsagha DS, Atanga MBS, et al. The kidney function trends in HIV/AIDS patients at the Nylon district hospital, Douala, Cameroon. Journal of AIDS and HIV research Feb 2011;3(2):30-7. 
